○小任非真，木下道子，宇高二立良，小池 立夫

(徳島大学医学部耳鼻咽喉科学教空)

\title{
1。はじめに
}

演者らはこれまで 3 回にわたって，DECtalk を用いて合成した無意 1 音節語音（合成母 音，57式語表，67式語表，時間歪語音など）と現在用いられている検査用テ・.フとの明樽 度を比䡈した。その粘果，無意 1 音節語音においては立分検査に使用し得ると思われた。 そこで今回は，中枢性㴔覚障害の鑑別診断に有用と思われる有意 1 音節語音（A．最小加 別テスト用語音，B，長母音短母音認知テスト用語音）を合成し，正常人における聴取結 果について娭討した。

\section{2 。検㭗用語音合成}

検查州語音は，音竍合成装面 DECtalkによ一て合成された純合成語音である。DECtalk は,ミニコンピュータ（DEC Professional 350）によって駆動され，Operating Systemは RT-11を用いた。

A。段小势別テスト用合成語音

歌 $\left[\begin{array}{lll}\mathrm{u} & \mathrm{t} & \mathrm{a}\end{array}\right]$ と裹 $\left[\begin{array}{lll}\mathrm{u} & \mathrm{r} & \mathrm{a}\end{array}\right] は[\mathrm{t}]$ と［r］といj子音を交換しただけでまったく意 味の異なった単語になる。このような音韻論的最小単位を最小限变えた場合に言葉の認知 にとのように影毞するかを調べるために、下に示した10对の単語を組み合わせ、これらを 任意に配列した娭査語音列を合成した。合成にあたっては，DECtalk 内部のパラメーター を変化させて聴觉印象上最も日本語語音に類似するように合成した。なお，下の㱟表は四 中らの作成した話表を参考にし，一部改变してある。

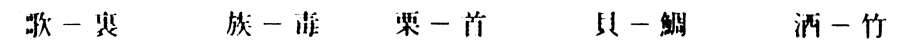

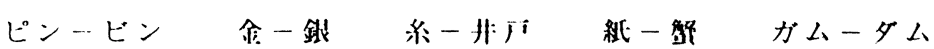

B。庋昨音短限音認知テスト用合成語音

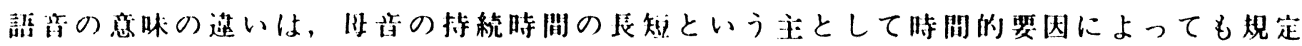
される。脳㧈伤の場合に离次聴党機能の障害としてこの母音の辰短の認知に障害を生ずる

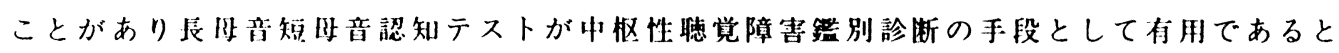
の説がある。これまでは，録音された肉声を用いて検査が行われてきた。しかし肉声に扔 いては，発音持続時䦌を細かく制御することは，困難であり，検查方法としてもな抄市

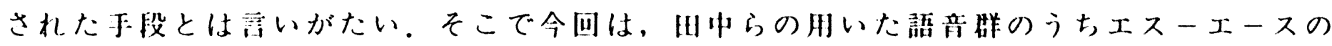

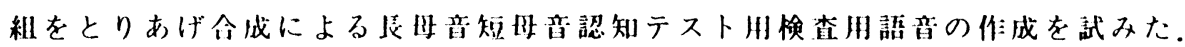

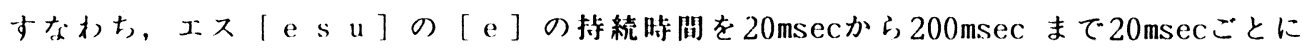

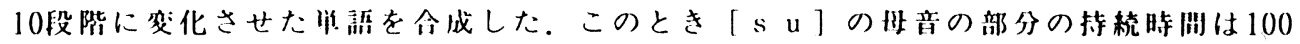

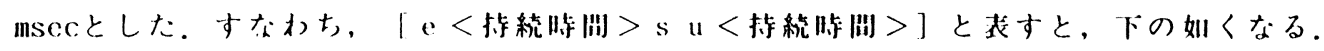




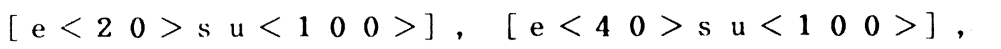

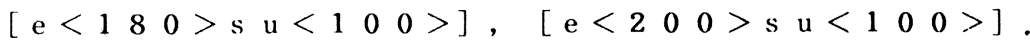

これらの 10 種類の持続時間の単語を任意に晒列した語音列を 2 種類合成した。

\section{3. 方法および对象}

聴力検査室内で，通常の語音聴力検查と同様に，ヘッドフォンを用いてMCL-1 evel 両耳 聴取にて施行した。

耳疾患のない健常成人10名を対象として，合成した語音を用いた聴取テストを行った。 (男5 名，女5名，25 46才)

4. 結果

\section{A 、最小刑別テス卜}

10 組の単語の正解染の平肉は，62\%であった。特に正当事の低かった単語は紙一㧘の 組だった。これまでの DECtalkの合成語音の明睹度テストでは虽答の多かったのはナ行， マ行でありその結果と良く一致していた。

B。長姆音短母音認知テスト

[e] の持繶時閑が $100 \mathrm{msec}$ 以下ではエスに $160 \mathrm{msec}$ 以上ではエースに認知される項向 がみられた。

\section{5.考察}

A．最小加別テストに护いては，明暸度が以前の単音節単語のデー夕と比較すると低か ったが、これは，日本語のアクセントを十分に合成できなかったのが原因ではないかと考 えられた。以後，改良の必要があると思われる。

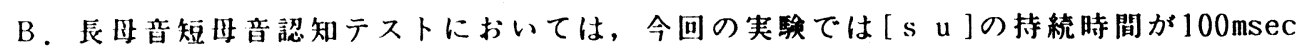
のみであり，後続音節の長さによって認知に差が出ることが考えられた。本方法では, 持

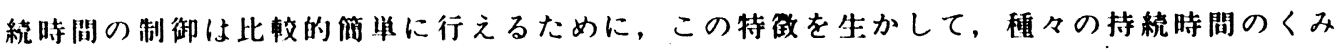
あわせを作成することも必要であると思われた。さらに改良を重ねて，従来の検査とも組 み合わせたテストバッテリーにしたいと考えている。

<参考文献 $>$

田中美郷他，：上位中枢性聴覚障害の臨床的検查法。67 102：䋛と僡賞障害,

篗原出版, 1981 